\title{
研究室紹介 \\ 岩手大学 農学部 応用生物化学科 食品工学研究室
}

\author{
三浦 靖*
}

(原稿受理：2021 年 2 月 12 日)

\section{1.はじめに}

レオロジー学会誌の新企画である「研究室紹介」も, 14 回目に達した。ささて, 食品の製造段階, 保蔵・流通段階, 消 費段階では, 食品素材および加工食品のレオロジー特性が取 り扱い性や品質に深く関わっている。 そこで, 活躍する学問 がレオロジーであるといえる。筆者が大学で担当している 「食品工学」は, 農芸化学に属しており, その一般な理解は, 「生命・食・環境の 3 つのキーワードに代表されるようなバ イオサイエンス (生命科学) とバイオテクノロジー（生命工 学）を中心とする多彩な領域の総合科学としての大きな学問 分野である。そして, その研究領域には, 環境科学・バイオ マス利用, 有機化学. 天然物化学, 酵素, 食品, 微生物, 動 物, 植物, 糖鎖生化学 - 糖鎖工学, 生物化学工学, 新技術 (先端バイオ計測, コンビバイオ工学等) がある」（日本農芸 化学会パンフレットの記載）である.

本稿では, 筆者が運営している研究室の沿革, 研究室の現 在, 最近の研究内容を紹介し, 食品科学でのレオロジーの重 要性を述べる.

\section{2. 岩手大学の概要}

岩手大学が所在する盛岡市は, 岩手県（人口約 121 万人） のほぼ中央に位置する人口約 29 万人の県庁所在地であるの みでなく, 1982 年に東北新幹線が開通して以来, 北東北の 中核都市として急速に発展してきた。本学は, 盛岡駅から北 へ約 $2 \mathrm{~km}$ という市街地にありながら, 緑に囲まれた広大な 自然公園を思わせるキャンパスとなっている。，その中に 4 学 部 (人文社会科学部, 教育学部, 理工学部, 農学部) および 教育研究支援施設が集まっている。

\section{3. 研究室の沿革}

岩手大学農学部の前身である旧盛岡高等農林学校は, 我が 国最初の高等農林学校として 1902 年に設置され, 2013 年に は創立 110 周年を迎えた。1991 年 4 月に 6 学科体制（農学科, 農芸化学科, 林学科, 畜産学科, 農業土木学科, 農業機械学

\footnotetext{
* ₹ 020-8550 岩手県盛岡市上田三丁目 18 番 8 号
}

E-mail : mako@iwate-u.ac.jp
科）が 3 学科体制（農林生産学科, 応用生物学科, 農業生産 環境工学科）に改組された。このときに農業生産環境工学科 に『食品工学研究室』が新設され, 種谷真一教授（前雪印乳 業（株）技術研究所所長）が初代教授として着任された。 1997 年 3 月には種谷教授が定年退職され，1999 年 10 月に小 林昭一教授（前農林水産省食品総合研究所食品理化学部長） が 2 代目教授として着任された。 2000 年 4 月に 4 学科体制 (上記 3 学科, 獣医学科) が 3 学科体制（農業生命科学科, 農林環境科学科, 獣医学科) に改組され, 当研究室は農業生 命科学科に移籍した。その後, 2004 年 4 月には国立大学法 人岩手大学が設立され，2005 年 3 月に小林教授が定年退職 された. 2007 年 4 月に教員組織を学部・大学院から独立さ せて全学的に一元化して再編し, 農学部は 3 学科体制から 5 教育課程体制（農学生命課程, 応用生物化学課程, 共生環境 課程, 動物科学課程, 獣医学課程) に再編され, 当研究室は 応用生物化学課程に所属した。そして，2016年4月には「震 災復興・地域創生」,「イノベーション創出」,「グローバル人 材育成」の理念のもと, 地域の課題に世界の視点で応える教 育・研究体制の強化に向け, 農学部は 6 学科（植物生命科学 科, 応用生物化学科, 森林科学科, 食料生産環境学科, 動物 科学科, 共同獣医学科) に改組され, 当研究室は応用生物化 学科に所属した。

\section{4. 研究室の現在}

食品の製造では,「安全で, おいしくて, 健康維持に役立 つ食品を，いかに環境に負担をかけずに効率よく，安価に，

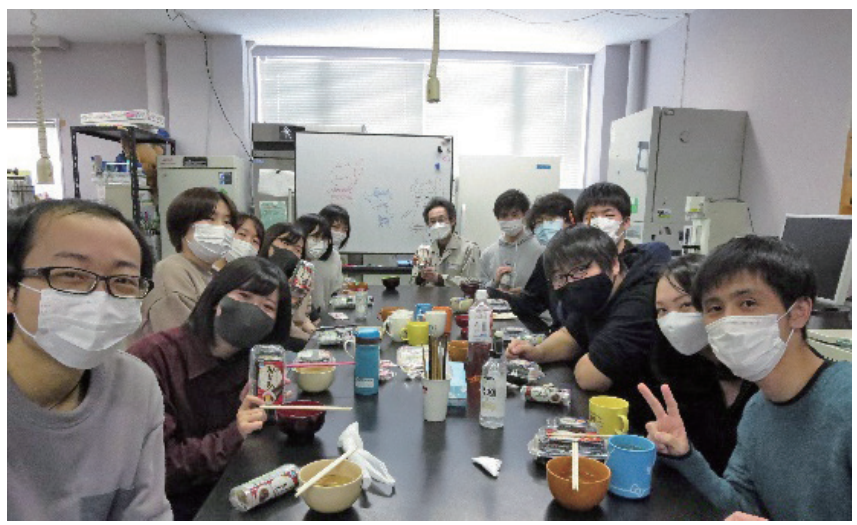

Fig. 1 研究室員（沈黙の恵方巻き, 2021 年の恵方は南南東). 


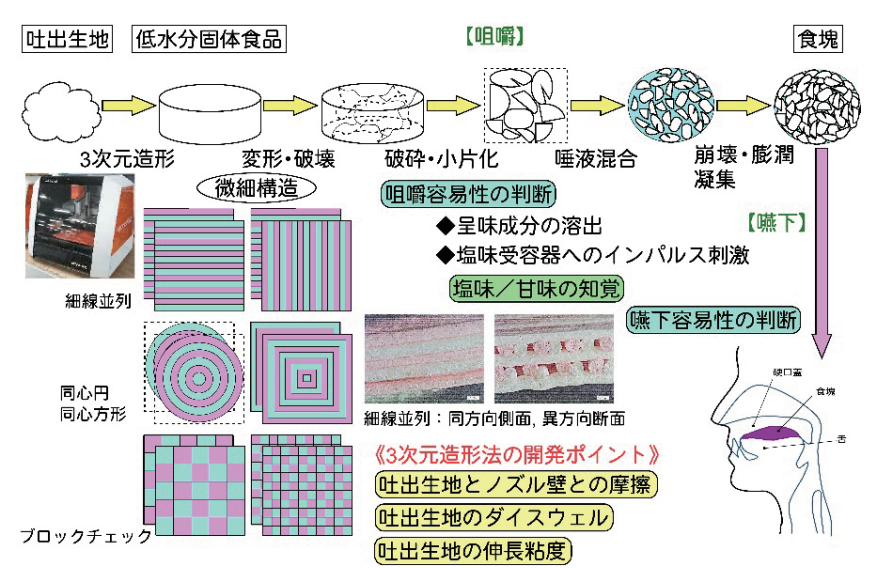

Fig. 23 次元造形法による低塩化・低糖質化食品および咀嚼・嶼下 困難者対応食品の開発イメージ。

安定した品質で創るか」が重要事項である。そこで, 食品に 本来的に具備している栄養的・嗜好的価值を損なうことなく 食品を加工, 包装, 保蔵, 流通するための種々の単位操作な らびにその連結系の効率を, 物質的かつエネルギー的に高め ることを目的とする応用科学である食品工学が活躍している. この食品工学が当研究室の対象領域である. 当研究室は本年 度で 30 年目を迎え, 教員 1 名 (筆者), 特任研究員 1 名, 修 士課程学生 4 名, 学部 4 年生 3 名, 学部 3 年生 4 名, 学部研 究生（留学生） 1 名の総勢 14 名で構成されている (Fig. 1). 当研究室では, 考える力の鍛錬, 問題解決型人材の育成, プ ラス発想型人材の育成を教育方針にして, 実学としての食品 工学の構築と普及に努めている。 そして, 研究テーマのほと んどが民間等との共同研究の形態をとっており, 食産業に適 用できる研究成果を生み出すように心掛けている.

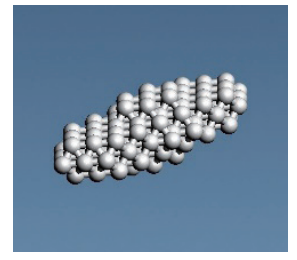

Fig. 3 剛体粒子 125 個で構成した米飯粒モデル.
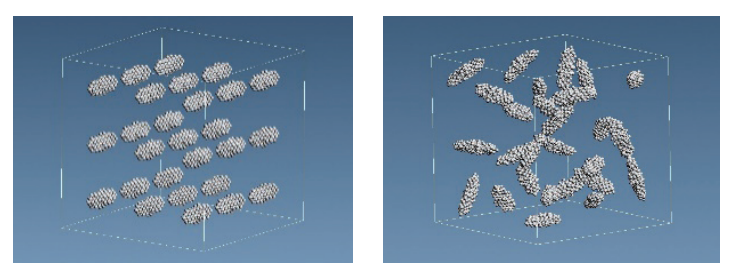

Fig. 427 個のセルに米飯粒モデルをランダム方向に配置させた米飯塊モデル
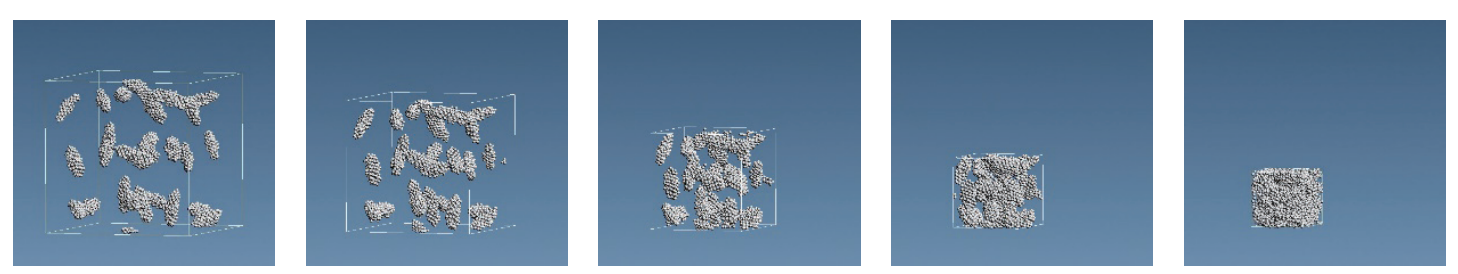

Fig. 53 軸等方圧縮した米飯塊モデル． 